\title{
Past, Present and Future Catheter Technologies and Energy Sources for Atrial Fibrillation Ablation
}

\author{
Inderpal Singh, Adam Price, Zachary Leshen and Boaz Avitall \\ University of Illinois at Chicago, IL
}

USA

\section{Introduction}

Atrial fibrillation (AF) is one of the most common tachyarrhythmias, with an incidence that continues, especially among the elderly where it affects upto $7 \%$ of the population. Due to the associated morbidities, including the risk of stroke, heart failure and impaired quality of life, numerous modalities have emerged for the treatment of atrial fibrillation. In recent years, an increasing number of patients are being treated with catheter ablation in an effort to restore sinus rhythm and decrease the associated co-morbidities. Compared to other treatment modalities, primarily that of pharmacotherapy, ablation of AF offers the unique opportunity to restore sinus rhythm and its associated benefits without the associated risks of anti-arrhythmic medications. These benefits, however, must be weighed against the known risks of ablation, which include perforation, cardiac tamponade, pulmonary vein stenosis and esophageal injury. It has been well described previously that premature atrial contractions (PACs) originating from the pulmonary veins are an important trigger for the initiation of AF. The sources of these PAC s are believed to be related to the presence of left atrial myocardial tissue that extends into the pulmonary vein. Consequently, most ablation strategies attempt to achieve electrical isolation of the pulmonary veins for the treatment of paroxysmal AF. Different energy sources combined with innovative catheter technologies are likely to improve the success rates of AF ablation.

\section{Radiofrequency lesions}

Radiofrequency (RF) energy is currently the most widely used energy source for performing catheter ablation procedures. RF generators deliver alternating current at frequencies too high to depolarize the myocardium between 500 and $1000 \mathrm{KHz}$ (Haines 1993 and Skanes et al 2003). When using a $4 \mathrm{~mm}$ catheter ablation tip, the radiofrequency energy used ( 20 to $50 \mathrm{~W}$ ) is often generated from a $550 \mathrm{KHz}$ electrosurgical unit and is delivered for 30-120 seconds (Manolis et al 1994). Most commonly the RF power is delivered between a $8 \mathrm{~F} 4-8 \mathrm{~mm}$ catheter ablation tip and a dispersive reference patch applied to the skin. The application of RF energy between the small ablation tip and the dispersive electrode results in the greatest resistance to the current flow at the catheter tip to tissue interface. This results in resistive heating, and consequently leads into lesion 
formation at the catheter to tissue interface. Deep tissue heating is consequence of conductive heating which is responsible for deep lesion formation. Conductive heating diminishes as a function of $1 / \mathrm{r}^{4}$ where ' $\mathrm{r}$ ' equals the distance from the point of maximal resistive heating (Hoffmann et al 1992 and Avitall et al 2004). Tissue temperatures above $45{ }^{\circ} \mathrm{C}$ result in increase in cytosolic calcium concentration due to increased permeability, while sarcoplasmic ATPase is inhibited at temperatures above $50^{\circ} \mathrm{C}$. Above $50^{\circ} \mathrm{C}$, irreversible tissue damage has been documented (Haines DE 1993 and Inesi et al 1973). At $60^{\circ} \mathrm{C}$, collagen denaturation occurs, with loss of elasticity and compliance of the ablated tissues.

\subsection{RF ablation non irrigated tip catheter}

The depth of lesion size increases as the temperature increase at the interface up to $100^{\circ} \mathrm{C}$. Above this temperature, the plasma starts boiling resulting in coagulum formation at the tip. This can lead to clot embolization, a sudden increase in impedance, loss of thermal conductivity, and ineffective tissue heating. Non-irrigated catheters are available with 4$5 \mathrm{~mm}$ and $8 \mathrm{~mm}$ length tip ablation electrodes with an integrated thermocouple to monitor the tip temperature. With the $8 \mathrm{~mm}$ catheter, a large portion of the electrode is exposed to flowing blood which cools the tip allowing for the application of higher RF power and the creation of larger lesions.

A thermocouple is integrated at the tip for monitoring the temperature during ablation. The new generation RF generators can help to titrate the power up and down until the desired tip temperature is reached. This is called temperature guided RF ablation (Skanes et al, 2003). Nowadays the generators are capable of opting between temperature guided or power guided RF ablation. The risk of a thromboembolism after LARFA (Left atrial radiofrequency ablation) is $1.1 \%$, with most events occurring within 2 weeks after the procedure using $8 \mathrm{~mm}$ tip catheter. (Oral et al 2006)

\subsection{Irrigated tip electrode catheter}

The irrigated tip electrode catheter (Figure 1) has $4-5 \mathrm{~mm}$ ablation electrode. The presence of irrigation helps to keep the temperature at the tissue-electrode interface lower, thereby permitting improved delivery of RF energy to deeper tissues. Ultimately, this can facilitate the creation of more complete, and transmural, radiofrequency lesions. Additionally, irrigation at the site of ablation has also helped to minimize thrombus formation at the ablation site as well. The saline used for irrigation can be circulated within the electrode (closed loop system), or open irrigation system that flushes saline through openings in the ablation electrode (Budde et al 1987, Grumbrecht et al 1998, Kongsgaard et al 1997, matsudairi et al 2003, Nakagawa et al 1998, Wittkampf et al 1989 and Yokoyama et al 2006). A major limitation of this catheter is the poor correlation of the tip temperature with the tissue temperature, often resulting in RF being curtailed and therefore incomplete lesions are made. The incidence of silent thromboembolic event in post ablation atrial fibrillation patients is $8.3 \%$ in irrigated tip catheter, $38.9 \%$ in duty cycled multielectrode catheter and $5.6 \%$ in cryoballoon (Gaita et al 2011). The duty cycled and cryoballoon ablation catheters have further been explained in the chapter. 
A. Closed Loop Catheter

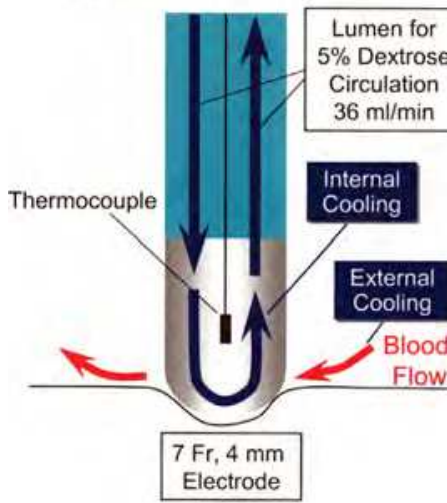

B. Open Irrigation Catheter

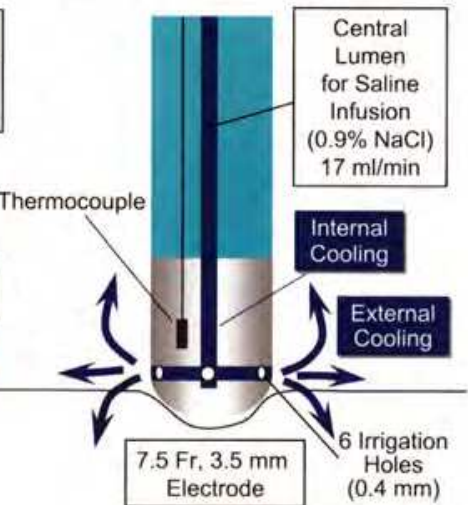

Fig. 1. Irrigated closed loop and open irrigation electrode catheter (Yokoyama et al 2006).

\section{Irrigated tip catheter with contact sensor}

RF ablation is dependent on good tissue contact where the ablation electrode is firmly embedded in the targeted tissue. The contact angle and the force between the tip of the catheter and the tissue surface play a major role in the characteristics of the lesion. Irrigated tip catheters with contact sensors can be used to estimate the contact force and angle (Figure 2). The catheter tip in this case is equipped with a deformable body that makes contact with the myocardial tissue. When subject to contact forces exerted by the tissue, the deformable body translates these forces into changes in wavelengths by optical fibers present within the catheter. Ultimately, these changes in wavelength are transformed via a computer algorithm to display both catheter vectors as well as contact force. The benefit of this catheter is that the combination of appropriate angle and force can be used to generate maximum transmurality with minimum incidence of steam pop and thrombus formation. (Schmidt et al 2009)

\section{Spiral catheter}

Another example of a catheter that is designed to specifically isolate the pulmonary vein (PV) Ostia resembles a corkscrew shape (Figure 3). This catheter is equipped with four 12 $\mathrm{mm}$ coil electrodes, with two thermistors placed at the edges of each coil to regulate the RF power, adjusting to the maximal sensed temperature from each thermistor (Avitall et al 2005). Standard radiofrequency generator with specialized interface was used.

The ablation catheter is introduced into the PVs via a 9F sheath. Once the tip of the catheter is in the PV, the sheath is withdrawn while maintaining the catheter position in the PV. As shown below, the spiral catheter expands within the vein and the coil electrodes are embedded within and under the orifice of the PV [figure 4]. Prior studies using this catheter demonstrated no visible PV narrowing during final PV angiography. PV circumferential lesions were documented in PVs and no PV stenosis was documented. One drawback however was the requirement to rotate the catheter position to create a circumferential lesion. 

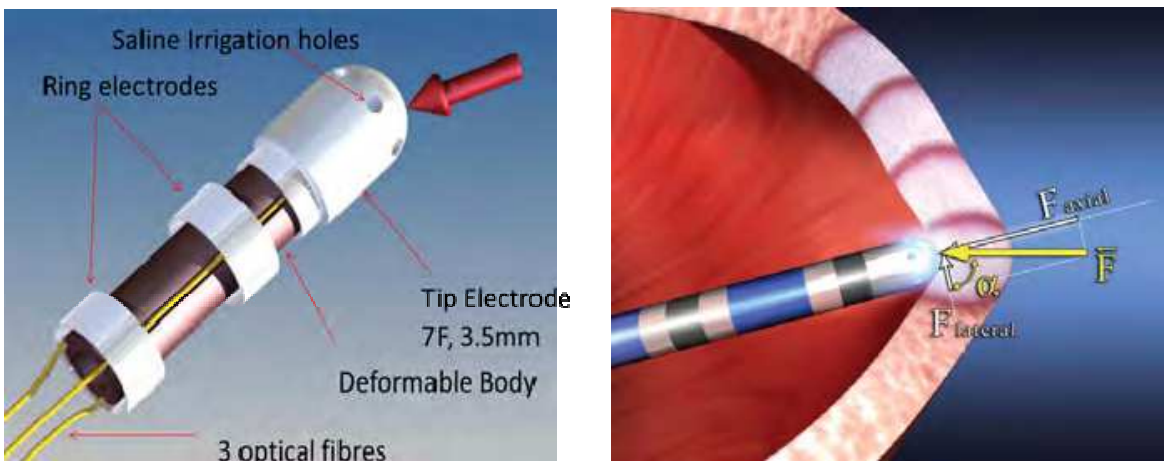

Fig. 2. Irrigated tip catheter with Contact sensor (Yokoyama et al 2008).
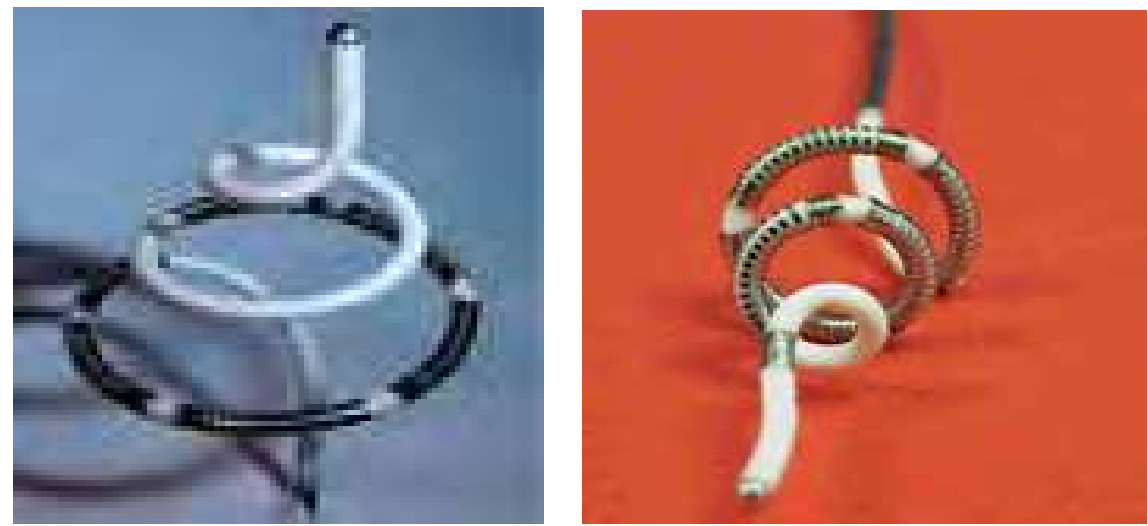

Fig. 3. PV ostia spiral catheter (Avitall et al 2005).
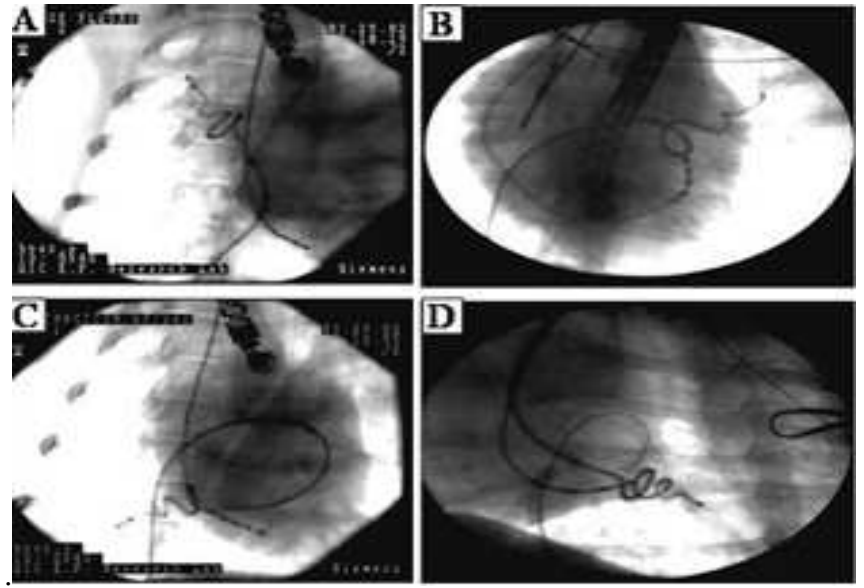

Fig. 4. Spiral catheter in Pulmonary veins, the spiral catheter expands within the vein and the coil electrodes are embedded within and under the orifice of the PV. 


\section{The duty cycled multi electrode catheter}

The pulmonary vein ablation catheter (PVAC) or duty cycled multi electrode catheter (Ablation Frontiers, Inc., Carlsbad, CA, USA) is a 9F, over-the-wire, circumlinear (diameter $25 \mathrm{~mm}$ ), decapolar mapping and ablation catheter (Figure 5). The $3 \mathrm{~mm}$ long platinum electrodes have an outer diameter of approximately $1.5 \mathrm{~mm}$ and are spaced $3 \mathrm{~mm}$ apart. Each electrode contains a thermocouple positioned on the surface contact side of the electrode. The catheter has 2 control handles. One allows bidirectional deflection of the shaft and the other is used to move the distal tip forward along the $0.032 \mathrm{~mm}$ guidewire, allowing a change of the catheter from its circular shape to a spiral configuration and finally to a longitudinal shape. The catheter is advanced through the sheath in its longitudinal shape and then deployed in the atria with the guidewire positioned in the vein (Boersma et al 2008). The GENius RF generator (Ablation Frontiers, Inc., Carlsbad, CA, USA) is a multichannel, dutycycled RF generator capable of independently delivering energy simultaneously to a maximum of 12 electrodes. RF energy can be delivered in unipolar (between ablation electrode and reference patch) and bipolar (between 2 adjacent ablation electrodes) configurations. Pairs of electrodes can be selected independently. During RF application, energy delivery is controlled by a software algorithm that modulates power to reach the user-defined target temperature $\left(60^{\circ} \mathrm{C}\right)$, but always limits power to a maximum of $10 \mathrm{~W}$ per electrode. In this way, the ablation is "temperature controlled". Although this ablation technology limits the peak power to $10 \mathrm{~W}$, lower than with a non-irrigated $4 \mathrm{~mm}$ tip catheter, the current density applied at the tissue surface is approximately the same due to the smaller surface area of the electrodes. One limitation however is that achieving PV isolation requires rotation of the catheter to create overlapping circumferential lesions (Boersma et al 2008). Boersma et al studied 98 patients with paroxysmal or persistent AF to evaluate the feasibility and safety of this multielectrode catheter. All targeted PVs were isolated using this catheter, and follow-up after 6 months without antiarrhythmic drugs showed freedom from AF in $83 \%$ of patients. This study also demonstrated that fluoroscopy and procedural time appear to be shorter than those associated with current AF ablation techniques, without the need for sophisticated mapping and/or steering modalities (Wijffels et al 2009).

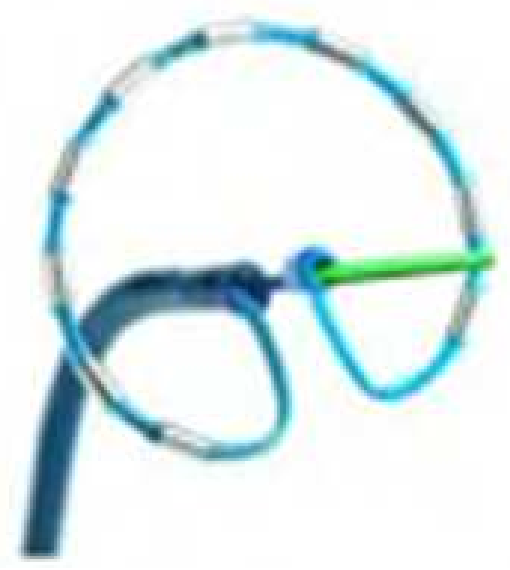

Fig. 5. PVAC (Decapolar Mapping and Ablation Catheter) (Wijffels et al.). 


\section{Loop catheter}

The loop catheter design for the creation of linear lesions in an effort to ablate AF was introduced in 1997. There are two main loop catheter systems, mostly used for experimental studies (Boston Scientific, EP Technologies, Sunnyvale, CA, USA) (Avitall et al 1999). Both catheter designs are shown in Figure 6. The first catheter system has twenty four $4 \mathrm{~mm}$ ring electrodes that can create loops in the atria. In an effort to increase the efficiency of the ablation system, the second loop catheter was designed with fourteen 12-mm long coil electrodes $2 \mathrm{~mm}$ apart, equipped with two thermistors that were positioned at the two edges of each coil. The power is regulated to the maximal temperature measured between the two thermistors. Depending on the magnitude of the pullwire retraction and the size of the catheter portion extending from the sheath, the electrode portion of the catheter can form loops of various sizes. The body of the catheter applies pressure on the thin atrial walls and forces them to stretch around the catheter, maintaining consistent electrode-tissue contact along the entire length of the ablation portion of the catheter. Since the forces that are applied to the atrial walls are distributed along the catheter shaft around the loop, it is presumed that no single point is exposed to excessive forces. A locking mechanism holds the catheter and pullwire firmly in position. (Avitall et al 2002).

The most important determinant in the effective creation of a RF lesion is the electrodetissue contact. Using the variable loop concept, the globular shaped atrial chambers will adapt around the catheter providing continuous contact. When using temperature control with this technology, over $90 \%$ of the lesions created in both atria were both contiguous and transmural while minimizing the incidence of significant rises in impedance. The catheter can be used to create linear lesions $6 \mathrm{~mm}$ wide and up to $16 \mathrm{~cm}$ long with minimal manipulation. Linear lesions were made by ablating at individual electrodes. Having multiple ablation electrodes on a single shaft allows for minimal catheter manipulation in creating long linear lesions and, therefore, may reduce both thromboembolic risk and radiation exposure. Once the catheter is in place, it remains in position for the duration of the power application to all of the electrodes (Avitall et al 2002).
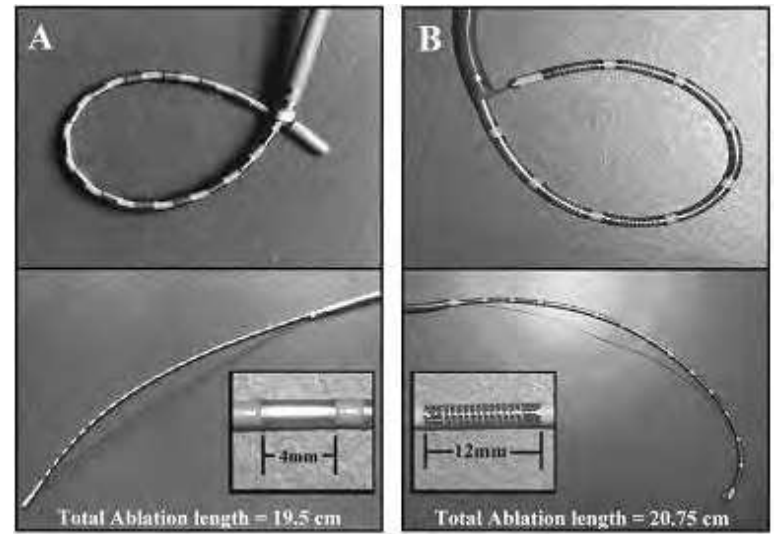

Fig. 6. The loop catheter system. (A) 8F with 24 4-mm-long ring electrodes spaced $4 \mathrm{~mm}$ apart. (B) 8F with 14 12-mm-long coil electrodes spaced 2-mm apart. A soft, braided pull wire attached to the distal tip of the catheter can be retracted into the long guiding sheath to deflect the catheter tip to create a loop of various sizes. (Avitall et al 1999). 


\section{Laser AF ablation}

A laser is a device that emits light (electromagnetic radiation) through a process of optical amplification based on the stimulated emission of photons. Emitted laser light is notable for its high degree of spatial and temporal coherence, unattainable using other technologies. Since duration and intensity of a laser can be controlled, it penetrates the tissue and scatters after getting absorbed in the tissue. Photon energy causes the vibrational excited state of surrounding molecules. This leads to generation of heat resulting in lesion creation. Laser energy can create deeper lesions with less reliance on thermal diffusion and can reduce tissue vaporization and coagulum formation. Because of its focused nature, it minimizes the collateral atrial tissue damage (Littman et al 1993). Two types of laser namely, Nd- YAG and Diode laser have been used in clinical application. Between them Diode laser with a wavelength of $980 \mathrm{~nm}$, can minimize endocardial disruption. (Littman et al 1993)

\subsection{Visually guided Laser balloon catheter}

Identification of the left atrial-pulmonary vein junction remains challenging, and additionally, creating contiguous lesions in a point by point manner to isolate the pulmonary veins (PV) is quite difficult. Balloon catheters provide an advantage in overcoming the challenge of charring and clot formation allowing for more precise lesion creation (Reddy et al 2004). The visually guided balloon catheter (Figure 7a) has an optic fiber head at the proximal end of the balloon and is equipped with an endoscope, permitting a visual angle of 110 degrees. When adequate tissue contact is made, tissue blanching will occur. If there is poor contact, however, then only free flowing blood is seen through the endoscope. Once the PV ostium is visualized, the next step is to use the optical fiber to target the laser arc at the appropriate tissue site. Correct identification of the ostium is critical to prevent formation of thrombus, which occurs when laser energy is focused on red blood cells. Keeping this in mind, the difference in the color of the light reflected is observed (seen as an arc) by the tissue and blood allows for assessment of contact. A red arc reflects contact with both tissue and blood, while green arc (Figure $7 \mathrm{~b}$ ) reflects balloon contact with tissue representing the target of ablation using this balloon technology. Once the arc is appropriately positioned to target the tissue of interest, a continuous $980-\mathrm{nm}$ arc of laser energy is delivered. To avoid the overheating of myocardial tissue, sterile cooling fluid is circulated inside the balloon. Multiple arcs of ablation are applied to "stitch" individual lesions together to achieve a continuous circumferential lesion set.

Studies utilizing visually guided balloon catheter ablation demonstrated long-term freedom from recurrence of atrial fibrillation at $67 \%$, a rate comparable to that achieved with radiofrequency ablation (Reddy et al 2004). The delivery of deeper ablation energies in the pulmonary vein results in an increased risk of PV stenosis. The interface of the laser balloon catheter remains well outside the PV with the arc is projected on the ostium resulting in a decreased risk creating PV stenosis.

To prevent esophageal injury intraoperative temperature monitoring of the esophagus is done. If the temperature rises then the arc is either advanced or retracted.In addition there is less incidence of pericardial tamponade because of the controlled energy delivery. (Reddy et al 2004). 

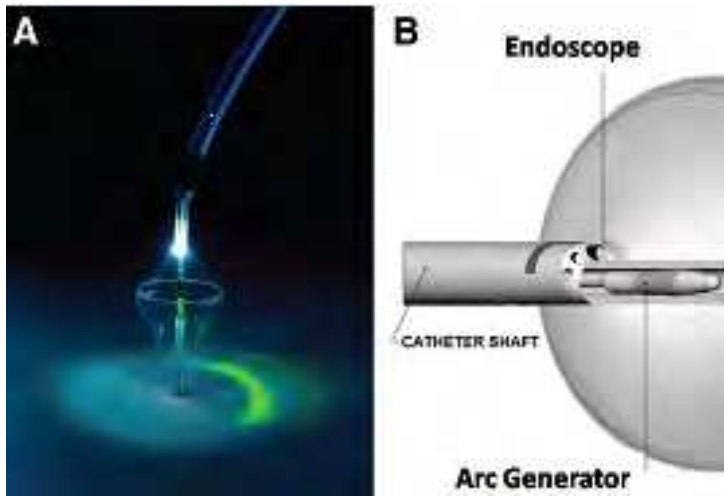

Fig. 7a. Panel A visually guided balloon catheter displaying the green laser arc. In panel B Distal end of the catheter is shown. Catheter shaft endoscope and arc generator can be seen. (Reddy et al 2008).

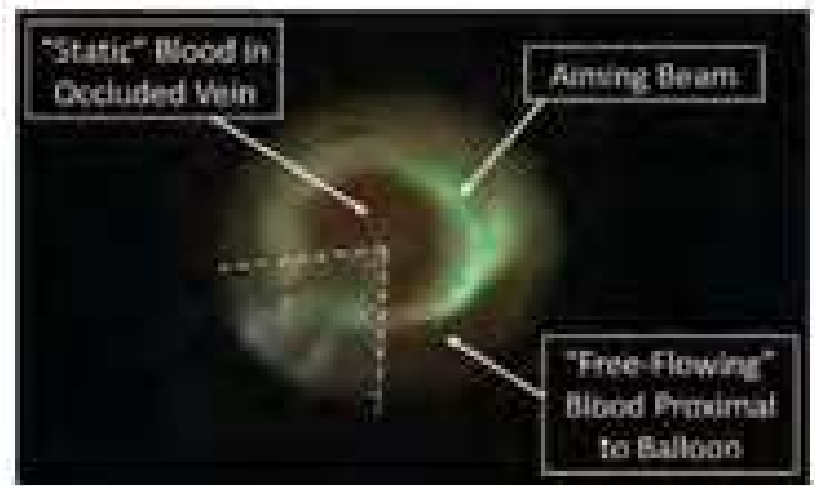

Fig. $7 \mathrm{~b}$. In this figure, the arc of laser can be seen. The green light signifies the tissue and red light signifies the blood in the vein.

\section{High intensity focused ultrasound balloon system}

The High intensity focused ultrasound balloon system (HIFU) is a dual balloon in balloon design (Figure 8). The steerable HIFU catheter, a 10F catheter equipped with a $24 \mathrm{~mm}$ diameter balloon, is advanced over the guidewire to the PV orifice, assisted by fluoroscopy and phased array intracardiac ultrasound (ICE) guidance. The anterior balloon is filled with fluid and the posterior with carbon dioxide. The interface created by the fluid and gas becomes the reflective interface of the ultrasound waves. The radially directed ultrasound energy is reflected forward to create a circumferential zone of concentrated ablative energy just beyond the face of the balloon. The mechanism of lesion formation is based on the conversion of the high intensity focused acoustic energy which causes molecular vibration that releases thermal energy in cardiac tissue. The steep tissue temperature gradient $\left(2-5{ }^{\circ} \mathrm{C}\right.$ per second) reaches $65-100^{\circ} \mathrm{C}$ with little heating of the adjacent tissue. (Okumura et al 2008 and Kennedy et al 2003) 
The balloon technology allows complete, $360^{\circ}$ delivery of circumferential energy around the PV orifice, which may simplify the procedure. The balloon catheter has a predictable focused zone with very rapid achievement of lethal tissue temperatures. Power titration may control energy delivery and limit its impact on collateral tissue. This also highlights the need for careful monitoring of device positioning within the context of the geometry of the vein and adjacent structures. Use of balloons larger than the PV orifice may prevent injury of phrenic nerve or distal pulmonary veins.
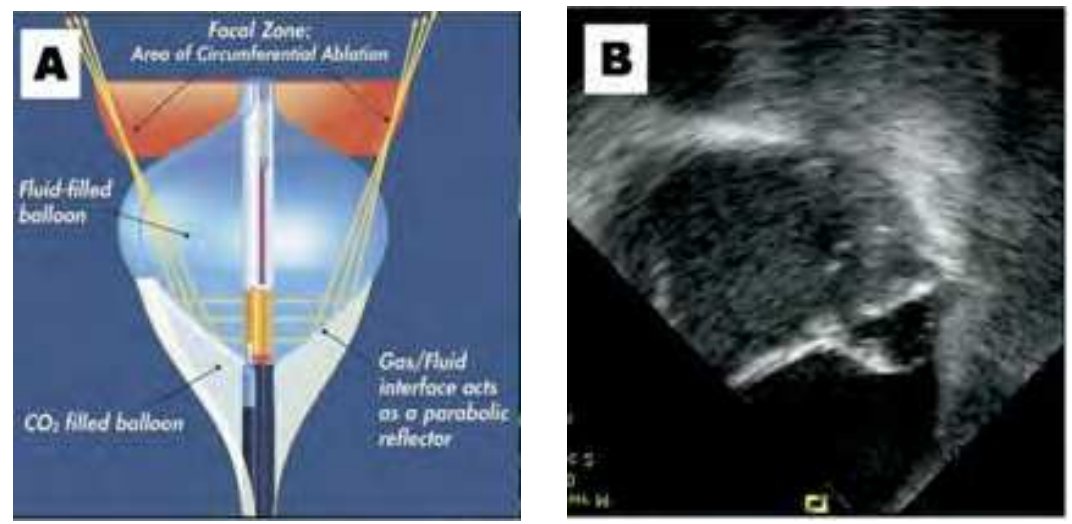

Fig. 8 A. High-intensity focused ultrasound balloon ablation system. B: An ICE catheter is placed within the coronary to visualize the HIFU catheter positioned at the ostium of the left inferior PV. (Reddy et al 2004).

\section{Cryothermal energy}

Cryotechnology has been used for cardiac ablation for three decades, but catheter based ablation has been a more recent development. Cryothermal energy produces lesions through hypothermic exposure, which is a very different mechanism of tissue injury as compared to heat ablation. Cryolesions are generated by application of a cryoprobe cooled with liquid nitrous oxide for $2-5$ minutes (Stobie et al 2003).

Progressive cooling of cardiac tissue slows down conduction and eventually blocks electrical activity when temperatures are reduced to 0 to $-20^{\circ} \mathrm{C}$. Permanent lesions are created when temperatures are reduced to -60 to $-80^{\circ} \mathrm{C}$ (Becker et al 2004).

Applying the cryoprobe to the tissue surface causes the formation of a hemisphere of frozen tissue, or iceball. Ice crystals formed are seen both intracellularly and extracellularly. The primary mechanism of cell death is fatal structural change in subcellular organelles and the mitochondrial membrane. The electron transport system, which normally utilizes the mitochondrial membrane, stops working, this leads to irreversible mitochondrial damage, and ultimately cell death characterized by coagulative necrosis. Extracellular ice causes additional compression and distortion of adjacent cytoplasmic components and nuclei.

Histpathologically RF lesions cause complete disruption of elastic fibers in comparison to normal appearing elastic fibers in cryolesions. Esophageal injury can occur in both RF and cryo, however cryo tissue injury is often benign and reversible. RF is compared with 
Cryoablation in the table 2 below. Moreover, tensile strength of the tissue remains intact in cryolesions. The potential advantages of cryoablation over RF for ablation include a low risk of endocardial disruption, reduced incidence of thrombus formation, and stable adhesion of the catheter tip to the endocardium during freezing (Arora et al 2009).

\subsection{Cryoballoon}

New cryoballoon technology can safely and effectively electrically isolate the PVs (Avitall et al 2004). Avitall et al studied the original cryo balloon technology and found that after multiple consecutive cryolesions no PV stenosis was noted 3 months after ablation. After cryo ablation, PV electrograms were eliminated and tissue recovery exhibits no cartilage formation. Acute tissue hemorrhage and hemoptysis are short term complications of cryoablation. Arctic front cardiac cryoablation catheter developed by CryoCath is shown in the figure 9. It creates cryo lesions by delivering liquid $\mathrm{N} 2 \mathrm{O}$ into the semi compliant balloon $(23 \mathrm{~mm}-28 \mathrm{~mm}$ diameter) and it is currently FDA approved for human PV isolation.

\begin{tabular}{|c|c|c|}
\hline & Advantages & Disadvantages \\
\hline Cryoablation & $\begin{array}{l}\text { 1. Marked differences in } \\
\text { lesion morphology (minimal } \\
\text { collagen formation). } \\
\text { 2. Preserved atrial } \\
\text { contraction and size. } \\
\text { 3. Marked reduction in the } \\
\text { risk of stroke (no char). } \\
\text { 4. Assessment of } \\
\text { arrhythmogenic source prior } \\
\text { to ablation (cool mapping). }\end{array}$ & $\begin{array}{l}\text { 1. Pressurized gas system. } \\
\text { 2. Complexity of control and } \\
\text { delivery } \\
\text { 3. Potential gas toxicity to the } \\
\text { operator and patient. } \\
\text { 4. Cooling of the patient. } \\
\text { 5. Intramural hemorrhage and risk } \\
\text { of hemoptysis. } \\
\text { 6. Requires tissue contact }\end{array}$ \\
\hline $\begin{array}{c}\text { Radiofrequency } \\
\text { Ablation }\end{array}$ & $\begin{array}{l}\text { 1. Simple, well-proven } \\
\text { technology. } \\
\text { 2. Ability to assess contact. } \\
\text { 3. Assessment of } \\
\text { temperature. } \\
\text { 4. Limited tissue damage. }\end{array}$ & $\begin{array}{l}\text { 1. Difficulty of uniform assessment } \\
\text { of tissue contact. } \\
\text { 2. Significant amount of collagen } \\
\text { and cartilage/calcification. } \\
\text { 3. Moderate risk of stroke, PV } \\
\text { stenosis. } \\
\text { 4. Atrial shrinkage. } \\
\text { 5. Moderate reduction in atrial } \\
\text { mechanical function. }\end{array}$ \\
\hline
\end{tabular}

Table 1. Comparison of cryoablation vs radiofrequency ablation (Yiu et al 2006).

\section{Virtual electrode and visualization catheter}

In the Virtual and visual electrode catheter a unipolar tip electrode is present with an endoscope circumferential to the tip it has a hood made up of a flexible elastopolymer membrane at the proximal end. This hood carries the circumferential light source bands for illumination. Consequently, this catheter provides the means of directly visualizing the target tissue that needs to be ablated. It is helpful in maintaining the contiguity of the lesions and also decreases the total procedure time. 


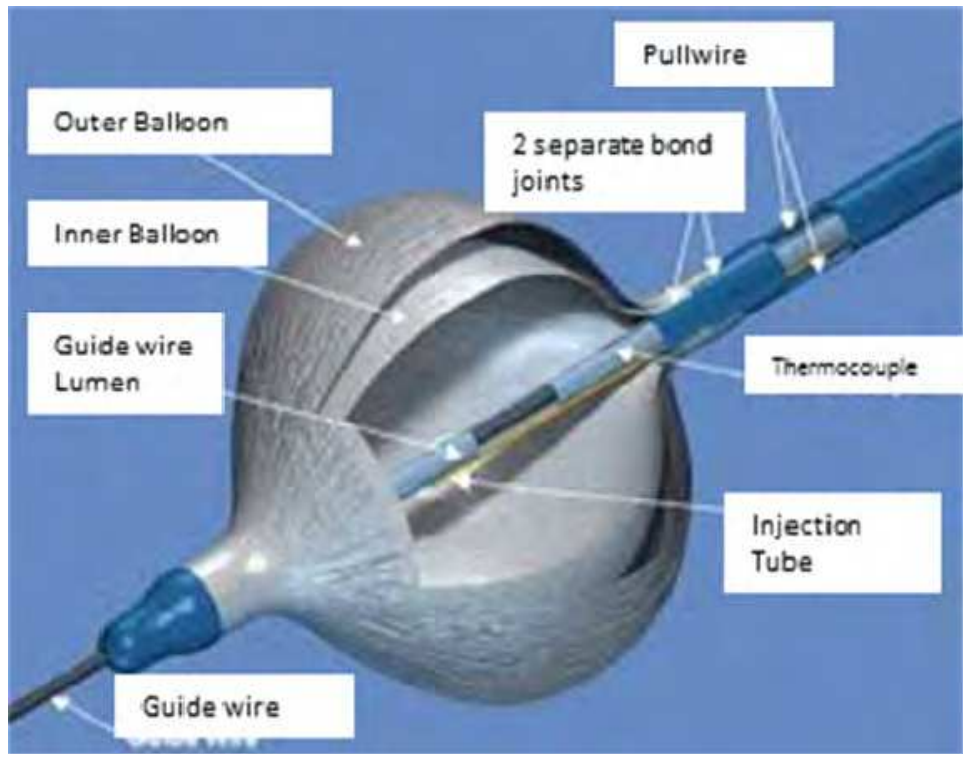

Fig. 9. Cryoballoon.

Additionally, ablation time can be controlled by visualizing blanching at the site where ablation is taking place, which is indicative of lesion formation (Figure 10 and 11). This catheter is constantly irrigated to evacuate the blood collection in the hood to increase the visibility of the tissue and also to cool the tip. Increased power leads to bubble formation in the hood and darkening of the tissue. Such lesions often result in steam pop. As a result, bubble formation and darkening of the tissue could be an indicator for lowering the power (Ahmed et al 2010).
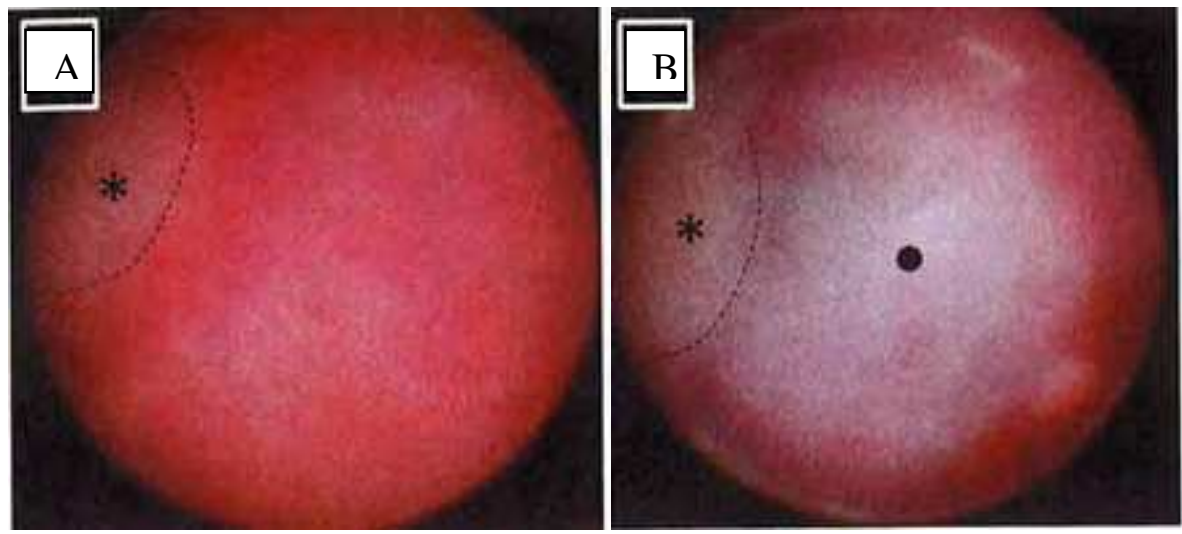

Fig. 10. Panel A: Visual field as seen through the endoscope. Pre ablation tissue is all red. Panel B: Post ablation tissue is pale as seen by the endoscopic visual field. * shows the previous ablation lesion with panel B demonstrating visualization of lesion contiguity (Ahmed et al 2011). 
Identified limitations of this catheter relate to technical difficulties of fixing the hood at the tissue interface, especially at rough surface of atrial tissue and edges around the pulmonary veins. The nature of the elastopolymer coating results in slippage of the catheter. It has also been seen to collapse, likely related to the force generated during lesion formation, requiring catheter replacement in certain cases (Ahmed et al 2011).
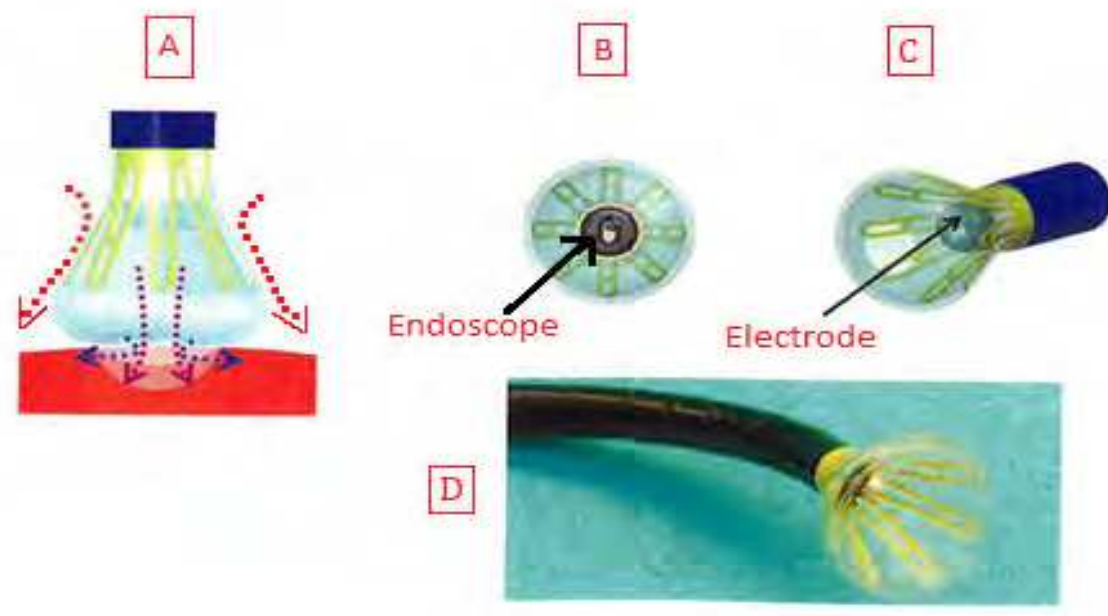

Fig. 11 A. Blue lines indicate the saline irrigation, purple lines indicate radiofrequency; Red lines indicate the flowing blood .B, C, D Virtual and visual electrode catheter from different angles. Hood with source of illumination can be seen clearly in panel C, endoscope and electrodes in the center are clearly visible in panel B. (Ahmed et al 2011).

Besides the technical limitations, current studies using this technology are limited by their small sample size, lack of application to atrial fibrillation and concerns over the volume of irrigation fluid delivered during the course of an ablation using this technology (Ahmed et al 2011).

\section{Microwave}

Microwave energy is an electromagnetic spectrum occupying the frequency range between $500 \mathrm{MHz}-100 \mathrm{MHz}$. When this electromagnetic radiation comes in contact with the biological tissues, it causes bipolar molecules (particularly water molecules) to oscillate and rotate under the influence of alternating electromagnetic radiation. This oscillation results in the conversion into kinetic energy, and finally collision of molecules cause heat energy formation (Johnson et al 1972). This (microwave induced) heat forms in deeper tissues as compared to RF where heat flows down the tissue interface to the deeper tissues via conductive heating, decreasing as a function of distance $\left(1 / \mathrm{r}^{4}\right)$. Microwave energy excites deeper tissues resulting in deep high temperature and larger lesions.

In fact, microwave induced scar seems to be the endpoint of two distinct pathways. The first pathway is the direct effect of microwave radiation, while the second is a result of ischemic damage. 


\begin{tabular}{|c|c|c|}
\hline Features & Radiofrequency & Microwave \\
\hline Clinical experience & +++ & + \\
\hline $\begin{array}{l}\text { Potential for } \\
\text { endocardial } \\
\text { Disruption }\end{array}$ & High & Low/ Medium \\
\hline Thrombogenicity & High & Medium \\
\hline Mapping capability & Limited & NO \\
\hline $\begin{array}{l}\text { Ability to create } \\
\text { transmural lesion }\end{array}$ & Require optimal Contact & $\begin{array}{c}\text { Optimal contact/ antenna } \\
\text { orientation required }\end{array}$ \\
\hline Lesion size & ++ & +++ \\
\hline Linear lesion & ++ & ++++ \\
\hline Perforation rate & LoW & LoW \\
\hline Procedure time & Shorter & Longer \\
\hline \multicolumn{3}{|l|}{$\begin{array}{c}\text { Injury to adjacent } \\
\text { structures: }\end{array}$} \\
\hline Phrenic nerve & +++ & Unknown \\
\hline Esophagus & +++ & ++ \\
\hline Coronary artery & +++ & + \\
\hline PV stenosis & +++ & No \\
\hline
\end{tabular}

Table 2.Comparison of Radiofrequency ablation and microwave ablations (Yiu et al 2006).

\section{Conclusion}

To date, many patients with refractory supraventricular tachyarrythmias have been successfully ablated without complications, however successful ablation of atrial fibrillation continues to pose unique problems to the cardiac electrophysiologist. While progress has been made on identification of the triggers and underlying substrate of atrial fibrillation, the tools necessary to isolate and ablate AF lags behind our knowledge of the mechanisms underlying this arrhythmia. The ideal catheter should possess the best mapping resolution to target the tissues of interest, create reliable transmural and contiguous lesions, and clearly discriminate between successful and unsuccessful lesion formation and maturation. Furthermore, the ideal catheter technology should be easily steered and adapt to the atrial anatomy reducing the procedure time. Further benefits of such an approach would be decreasing excessive exposure of radiation to the physician and the patient in the EP lab. So far, balloon devices seem to offer a unique promise, however lesion transmurality is still a question.

\section{References}

Avitall B., Lafontaine D., Rozmus G., Adoni N., Le K., Dehnee A., Urbonas A.; The safety and efficacy of multiple consecutive cryo lesions in canine pulmonary veins-left atrial junction. Heart Rhythm, (2004) Volume 1, Issue 2, Pages 203 - 209.

Avitall B., Urboniene D., Rozmus G., Lafontaine D., Helms R., and Urbonas A.; New Cryotechnology for Electrical Isolation of the Pulmonary Veins. J Cardiovasc Electrophysiol (March 2003) Volume 14 Issue 3, Pages 281 - 286.

Avitall B, Helms R, Koblish J, Seiben W, Kotov AV, Gupta GN. The creation of linear contiguous lesions in the atria with an expandable loop catheter. JACC 1999; 33(4):972-984. 
Avitall B, Urbonas A, Urboniene D, Rozmus G, Helms R. Linear lesions provide protection from atrial fibrillation induction with rapid atrial pacing. $\mathrm{J}$ of Cardiovasc Electrophysiol 2002; 13:455-62.

Avitall B, Aleksonis D, Koblish J, Chicos A, Mykytsey A, Taimisto M. New RF J shaped catheter design for creation of circumferential linear lesions and PVs isolation. Heart Rhythm, 20052 (5): S154.

Ahmed Humera, BA, Neuzil Petr, MD, Skoda Jan, MD, Sediva Luce, MD Kralovec Stepan, Reddy Y Vivek MD Initial clinical experience with a novel visualization and virtual electrode radiofrequency ablation catheter to treat atrial flutter 2011 heart rhythm Page 361-367

Arora Pawan K. MBBS, Hansen James C MD, Price Adam D. MD, Koblish Josef , Avitall Boaz MD PhD,FHRS An Update on the Energy Sources and Catheter Technology for the Ablation of Atrial Fibillation 2010 JAFib

Arora PK, Hansen JC, Latchamsetty R, Avitall B. Is Cryo a better energy source than radiofrequency for AF ablation in preventing esophageal injury?J Atrial Fibrillation 2009; 1(6): 321-327

Becker, R., \& Schoels, W., Ablation of atrial f rhythmibrillation: Energy sources and navigation tools: A review. Journal of Electro cardiology, (2004), 37, 55-62.

Boersma LVA, Wijffels MCEF, Oral H, Wever EFD, Morady F: Pulmonary vein isolation by duty-cycled bipolar and unipolar radiofrequency with a multielectrode ablation catheter. Heart Rhythm 2008; 5:1635-1642.

Budde T, Borggrefe M, Podczeck A, Jacob B, Langwasser J, Frenzel H, Breithard G. Radiofrequency ablation: an improvement of ablation techniques in comparison to direct-current delivery. In: Breithardt G, Borggrefe M, Zipes DP, eds. Nonpharmacological Therapy of Tachyarrhythmias. Mount Kisco, NY: Futura Publishing Company Inc; 1987:221-241

Haines David, Watson Denny Tissue Heating During Radiofrequency Catheter Ablation: A Thermodynamic Model and Observations in Isolated Perfused and Superfused Canine Right Ventricular Free Wall 1989

Demolin JM, Eick OJ, Munch K, Koukkick E, Nakagawa H, Wittkampf FHM. Soft thrombus formation in radiofrequency catheter ablation. Pacing Clin Electrophysiol. 2003; 25:1219-1222

Gaita Fiorenzo , M.D Franc Jean, Leclercq Ois , M.D, Schumacher Burghard, M.D, Scaglione Marco , M.D, Toso Elisabetta , M.D, Halimi Franck, M.D, Schade Anja, M.D Froehner Steffen, M.D, Ziegler Volker, M.D, Sergi Domenico, M.D, Cesarani Federico, M.D and Blandino Alessandro, M.D Incidence of Silent Cerebral Thromboembolic Lesions After Atrial Fibrillation Ablation May Change According To Technology Used: Comparison of Irrigated Radiofrequency, Multipolar Nonirrigated Catheter and Cryoballoon (2011 J Cardiovasc Electrophysiol, Vol. pp. $1-8)$

Gauri AJ,Knight BP. Catheter Ablation for Atrial Fibrillation; indian pacing electrophysiol j 2003 oct-dec;3(4):210-223

Grumbrecht S, Neuzner J, Pitschner HF. Interrelation of tissue temperature versus flow velocity in two different kinds of temperature controlled Catheter radiofrequency energy application. J Interv Card Electrophysiol. 1998; 2:211-219 
Haines DE The biophysics of radiofrequency catheter ablationin the heart: The importance of temperature monitoring. Pacing Clin Electrophysiology 1993;16 ( 3 pt 2): 586-591

Hoffmann E, Haberl R, Pulter R, Gokel M, Steinbeck G. Biophysical parameters of radiofrequency catheter ablation, international J Cardiol (1992); 13:213-233.

Inesi G, Millman M, Eletr S. Temperature-induced transitions of function and structure in sarcoplasmic reticulum membranes. J Mol Biol. (Dec 25, 1973);81(4):483-504

Johnson CC, Guy AW. Nonionizing electromagnetic wave effects in biological materials and systems. Proc IEEE. 1972; 60:692-709.

Kongsgaard E, Steen T, Jensen O, Aass H, Amlie JP. Temperature guided Radiofrequency catheter ablation of myocardium: comparison of catheter Tip and tissue temperatures in vitro. Pacing Clin Electrophysiol. 1997; 20:1252-1260

Kennedy JE, MBBS, MRCS1, Haar G R ter , MSc, PhD, DSc2 and Cranston D , DPhil, FRCS3 High intensity focused ultrasound: surgery of the future? 2003 British Journal of Radiology (2003) 76, 590-599

Littmann L, Svenson RH, Chuang CH, Splinter R, Kempler P, Norton HJ, Tuntelder JR, Thompson M, Tatsis GP: Neodymium:YAG contact laser photocoagulation of the in vivo canine epicardium: Dosimetry, effects of various lasing modes, and histology. Lasers Surg Med 1993; 13:158-167.

Manolis, A, Wang, P, \& Estes, M. Radiofrequency catheter ablation for cardiac tachyarrhythmias. Annals of Internal Medicine, (1994), 121, 452-461

Matsudaira K, Nakagawa H, Yamanashi SW, Wittkampf FHM, Pitha JV, Imai S, Lazzara R, Jackman WM. High incidence of thrombus formation Without impedance rise during radiofrequency ablation using electrode Temperature control. Pacing Clin Electrophysiol. 2003; 26:1227-1237

Nakagawa H, Wittkampf FHM, Yamanashi WS, Pitha JV, Imai S, Campbell B, Arruda M, Lazzara R, Jackman WM. Inverse relationship between electrode size and lesion size during radiofrequency ablation with active electrode cooling. Circulation 1998; 98:458-465

Nakagawa H, Yamanashi WS, Pitha JV, Arruda M, Wang X, Ohtomo K, Beckman KJ, McClelland JH, Lazzara R, Jackman WM. Comparison of in vivo tissue temperature profile and lesion geometry for radiofrequency ablation with a saline-irrigated electrode versus temperature control in a canine thigh muscle preparation. Circulation. 1995; 91:2264-2273

Okumura Yasuo ,MD, PhD,Kolasa Mark MD Johnson Susan BS,Bunch t Jared M.D,Benheird Henz M.D.,Brien Christine J. $\mathrm{O}$,Dylan Miller MD and Douglas Packer MDMechanism of Tissue Heating During High Intensity Focused Ultrasound Pulmonary Vein Isolation: Implications for Atrial Fibrillation Ablation Efficacy and Phrenic Nerve Protection September 2008 J Cardiovasc Electrophysiol, Vol. 19, pp. 945-951

Oral Hakan Chugh Aman, Özayd1n Mehmet, Good Eric, Fortino Jackie , Sankaran Sundar, Reich Scott, Igic Petar, Elmouchi Darryl, Tschopp David, Wimmer Alan, Dey Sujoya , Crawford Thomas, Pelosi Frank, Jr, Jongnarangsin Krit, Bogun Frank and Morady Fred Risk of Thromboembolic Events After Percutaneous Left Atrial Radiofrequency Ablation of Atrial Fibrillation Circulation 2006, 114:759-765

Perzanowski C, Teplitsky L, Hranitzky PM, and Bahnson TD; Real-Time Monitoring of Luminal Esophageal Temperature During Left Atrial Radiofrequency Catheter 
Ablation for Atrial Fibrillation: Observations About Esophageal Heating During Ablation at the Pulmonary Vein Ostia and Posterior Left Atrium. J Cardiovasc Electrophysiol, (February 2006) Vol. 17,pp. 166-170

Reddy Vivek Y., MD; Neuzil Petr , MD, PhD; Themistoclakis Sakis, MD; B. Danik Stephan , MD; Bonso Aldo , MD; Rossillo Antonio , MD; Raviele Antonio, MD; Schweikert Robert, MD; Ernst Sabine, MD; Kuck Karl-Heinz, MD; Natale Andrea, MDVisuallyGuided Balloon Catheter Ablation of Atrial Fibrillation Experimental Feasibility and First-in-Human Multicenter Clinical Outcome circulation 2009, pp 12-20

Reddy VY, Houghtaling C, Fallon J, Fischer G, Farr N, Clarke J, McIntyre J, Sinofsky E, Ruskin JN, Keane D: Use of a diode laser balloon ablation catheter to generate circumferential pulmonary venous lesions in an open-thoracotomy caprine model. Pacing Clin Electrophysiol 2004; 27:52-57.

Reddy Vivek Y. MD Neuzil Petr MD†, d'Avila Andre MD, Laragy Margaret BS, Malchano Zachary J MS, Kralovec Stepan †, J. Kim Steven MSł and. Ruskin Jeremy N MD Balloon catheter ablation to treat paroxysmal atrial fibrillation: What is the level of pulmonary venous isolation? Heart Rhythm 2008;5:353-360

Schmidt B , Kuck KH, Shah D, Reddy V, Saoudi N, Herrara C, Hindricks G, Natale A, Jais P, Lambert $\mathrm{H}$ Toccato multi center clinical study using irrigated ablation catheter with integrated contact force sensor: first resultsHeart rhythm. 2009;6:S536

Stobie P. \& Green M. Cryoablation for septal accessory pathways: Has the next ice age arrived? Journal of Cardiovascular Electrophysiology, (2003) 14, 830-831.

Skanes AC, Klein GJ, Krahn AD, Yee R. Advances in energy delivery. Coron Artery Dis. $2003 ; 14(1): 15-23$

Taylor Gregg W., G. Neal Kay, g Zheng Xiangshen , Bishop Sanford , Ideker Raymond E , Pathological Effects of Extensive Radiofrequency Energy Applications in the Pulmonary Veins in Dogs. Circulation. (2000);101:1736-1742

Wijffels MCEF, Oosterhout MV, Boersma LVA, Werneth R, Kunis C,Hu B, Beekman JDM, Vos MA. Characterization of In Vitro and In Vivo Lesions Made by a Novel Multichannel Ablation Generator and a Circumlinear Decapolar Ablation Catheter. October 2009 J Cardiovasc Electrophysiol, Vol. 20, pp. 1142-1148

Wittkampf FHM, Hauer RNW, Robles de Medina EO. Control of radiofrequency lesion size by power regulation. Circulation. 1989;80:962-968

Yokoyama Katsuaki , Nakagawa Hiroshi, Shah Dipen C, Lambert Giovanni Hendrik Leo Nicolas Aeby, Ikeda Atsushi, Pitha Jan V, Tushar Sharma, Lazzara Ralph and. Jackman Warren M Novel contact force sensor incorporated in irrigated radiofrequency ablation catheter Predicts Lesion Size and Incidence of Steam Pop and Thrombus ;Circulation: Arrhythmia and Electrophysiology Issue: Volume 1(5), December 2008, pp 354-362

Yiu KH, Lau CP, Lee K, Tse HF. Emerging energy sources for catheter ablation of atrial fibrillation. J Cardiovasc Electrophysiol 2006; 17:S56-61.

Yokoyama Katsuaki, MD, PhD; Nakagawa Hiroshi , MD, PhD;. Wittkampf Fred H.M, PhD;. Pitha Jan V , MD, PhD; Lazzara Ralph, MD; Jackman Warren M. , MD Comparison of Electrode Cooling Between Internal and Open Irrigation in Radiofrequency Ablation Lesion Depth and Incidence of Thrombus and Steam Pop Circulation Issue: January 2006, Volume 113(1), pp 11-19 


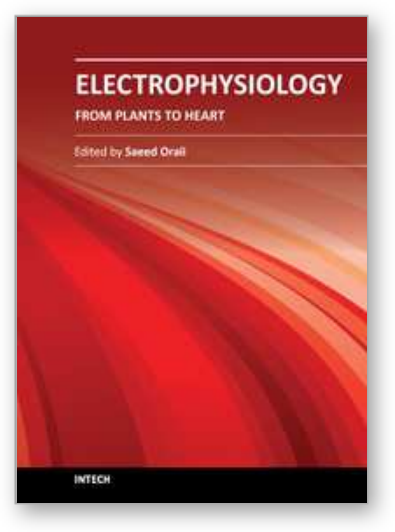

\author{
Electrophysiology - From Plants to Heart \\ Edited by Dr. Saeed Oraii
}

ISBN 978-953-51-0006-5

Hard cover, 202 pages

Publisher InTech

Published online 03, February, 2012

Published in print edition February, 2012

The outstanding evolution of recording techniques paved the way for better understanding of electrophysiological phenomena within the human organs, including the cardiovascular, ophthalmologic and neural systems. In the field of cardiac electrophysiology, the development of more and more sophisticated recording and mapping techniques made it possible to elucidate the mechanism of various cardiac arrhythmias. This has even led to the evolution of techniques to ablate and cure most complex cardiac arrhythmias. Nevertheless, there is still a long way ahead and this book can be considered a valuable addition to the current knowledge in subjects related to bioelectricity from plants to the human heart.

\title{
How to reference
}

In order to correctly reference this scholarly work, feel free to copy and paste the following:

Inderpal Singh, Adam Price, Zachary Leshen and Boaz Avitall (2012). Past, Present and Future Catheter Technologies and Energy Sources for Atrial Fibrillation Ablation, Electrophysiology - From Plants to Heart, Dr. Saeed Oraii (Ed.), ISBN: 978-953-51-0006-5, InTech, Available from:

http://www.intechopen.com/books/electrophysiology-from-plants-to-heart/past-present-and-future-cathetertechnologies-and-energy-sources-for-atrial-fibrillation-ablation

\section{INTECH}

open science | open minds

\section{InTech Europe}

University Campus STeP Ri

Slavka Krautzeka 83/A

51000 Rijeka, Croatia

Phone: +385 (51) 770447

Fax: +385 (51) 686166

www.intechopen.com

\section{InTech China}

Unit 405, Office Block, Hotel Equatorial Shanghai

No.65, Yan An Road (West), Shanghai, 200040, China

中国上海市延安西路65号上海国际贵都大饭店办公楼 405 单元

Phone: +86-21-62489820

Fax: +86-21-62489821 
(C) 2012 The Author(s). Licensee IntechOpen. This is an open access article distributed under the terms of the Creative Commons Attribution 3.0 License, which permits unrestricted use, distribution, and reproduction in any medium, provided the original work is properly cited. 